their implementation of law-making activity testifies to the episodicity of these studies, since the scientific study of these issues was carried out indirectly through a scientific analysis of other related legal phenomena and processes. As a result, in modern native legal science, there are no comprehensive studies of the content and essence of the legal status of courts in the mechanism of law-making activity. The author defines the peculiarities of the legal status of the courts of Ukraine as subjects of law-making.

Legal status of courts as subjects of law-making: 1) represents a special complex of legal competences of the abovementioned subjects regarding the determination of law-making activity, its further influence on it and the achievement of the law-making result; 2) characterized by a two-sided approach of understanding, according to which, on the one hand, the legal status of the court determines exclusively the actual status of the subject in the legal relationship, characterizing its role in law-making, and on the other hand, is based on understanding of the legal status as a category consisting of a set of elements, which determine the legal status of the court in the system of law-making legal relations.

Key words: legal status, legal status of courts, jurisprudence, law-making, law-making activity, participation of courts in law-making activity.

DOI: 10.33.66.3/2524-017X-2019-10-157-162

УДК 340.12

\author{
Андрій Свгенович Кубко, \\ кандидат юридичних наук, докторант відділу \\ теорії держави і права Інституту держави і права \\ ім. В.М. Корецького НАН України
}

\title{
ДЕРЖАВНІ ІНТЕРЕСИ І ПРАВА ЛЮДИНИ: ДЕЯКІ ПИТАННЯ СПІВВІДНОШЕННЯ
}

Постановка проблеми. В умовах сьогодення постає необхідність захисту територіальної цілісності, державного суверенітету, засад конституційного ладу, забезпечення реалізації державної політики в сфері правопорядку, оборони, безпеки. Тому виникає проблема найбільш ефективної реалізації державних інтересів.

Для забезпечення реалізації і захисту державних інтересів держава на рівні законів, підзаконного регулювання та правозастосовної практики вимушена використовувати правові механізми, які супроводжуються певним обмеженням приватних інтересів особи (або груп осіб), обмеженням прав людини і громадянина, говорячи термінологією практики Європейського суду з прав людини, втручанням держави у ці права та приватні інтереси. При цьому саме права людини, їх гарантії, захист і утвердження виступають однією із базових правових цінностей як у правовій системі України, так і з точки зору міжнародної спільноти. Діяльність держави, її органів, гілок влади по забезпеченню реалізації державних інтересів може входити в певний конфлікт із засадами захисту прав людини, їх гарантіями, процесом реалізації цих прав. Тому центральною проблемою є співвідношення між державними інтересами та правами людини. Мова йде про те, що реалізація державних інтересів за допомогою державно-правових механізмів повинна здійснюватись у балансі з гарантіями прав людини. Доктринальне розуміння проблем реалізації державних інтересів в правовій системі повинне грунтуватись на науково-теоретичних положеннях з проблематики інтересу як правової категорії, ролі і місця держави в системі суспільних відносин та їі завдань.

Аналіз останніх досліджень та публікацій. Останні наукові роботи в аспекті проблематики співвідношення інтересів держави і прав людини присвячені дослідженню природи державного інтересу, аналізу категорії законних інтересів, питань їх реалізації [1, с. 7]. Правова теорія наголошує на зорієнтованості діяльності держави, державно-владних повноважень, правових норм на меті забезпечення й утвердження прав людини. Знайшла розвиток теза про діяльність органів державної влади як один із засобів забезпечення реалізації прав і свобод громадян [2, с. 135]. Відзначають, що безумовною оцінкою ефективності права $\epsilon$ ефективність захисту прав, свобод і законних інтересів людини [3, с. 26]. У наукових роботах останніх років предметом дослідження ставала 
проблема гарантій прав людини в контексті аналізу питання здійснення державних повноважень [4, с. 127-141]. Окремо розглядалась проблематика міжнародно-правових гарантій прав людини, закріплених на рівні актів міжнародного права і практики міжнародних юрисдикційних установ по застосуванню положень міжнародних договорів в сфері прав людини [5, с. 128-152]. Одним із ключових питань, що $є$ сьогодні предметом дослідження зарубіжної науки в контексті співвідношення державних інтересів і приватних прав виступає міжнародно-правова відповідальність держав [6, с. 231-251], включаючи відповідальність внаслідок порушення державами прав людини. Важливе місце в проблематиці відповідальності держав займають науково-теоретичні підходи до проблеми балансу між інтересами держави та гарантіями приватних прав особи [7, с. 959-1020]. Мова йде про певну обмеженість повноважень держави такими гарантіями.

Мета статті полягає у виробленні підходів до правової природи державних інтересів у контексті їх співвідношення із інститутом прав людини, що повинне мати методологічне значення в рамках наукового аналізу проблеми державних інтересів в праві.

Основні результати дослідження. Важливе науково-методологічне значення в контексті дослідження питань співвідношення державних інтересів і приватних прав особи має, насамперед, проблема правильної ідентифікації державних інтересів. Нерідко інтереси державного апарату, посадових осіб, окремих державних органів, державних господарюючих організацій безпідставно розглядаються як державні інтереси, хоча в дійсності вони не $\epsilon$ державними. Намагання держави реалізувати ці інтереси як державні за допомогою державно-владних механізмів призводить до порушення прав особи, безпідставного, непропорційного обмеження приватних прав. Як наслідок, по-перше, виникають підстави для притягнення держави до відповідальності, в тому числі до міжнародної відповідальності за порушення норм міжнародного права в сфері захисту прав людини. Це призводить як до економічних збитків держави, наприклад, у вигляді виплати компенсації потерпілим особам за рахунок державних коштів, так і до репутаційної шкоди, що виражається зокрема в тому, що в світі утверджується репутація держави як країни, що не забезпечує захист прав людини, іноземних та внутрішніх інвестицій тощо. По-друге, дійсні державні інтереси залишаються у подібних ситуаціях не тільки не реалізованими, а й не ідентифікованими.

Наукове-теоретичне розуміння категорії державних інтересів повинне грунтуватись на доктринальних розробках щодо природи інтересу та інтересу в праві зокрема. При визначенні державних інтересів мають також враховуватись положення міжнародного права і практика міжнародних юрисдикційних установ, оскільки саме ця сфера відіграє сьогодні важливу роль у вирішенні питань відповідальності держав у зв'язку із проблемою державних інтересів.

У теорії права і в роботах із галузевих юридичних наук інтерес розглядається як складне явище, яке має структурний характер. Вказується, що інтерес містить у собі потреби та шляхи їх задоволення [8, с. 132], виступає відношенням суб'єкта до конкретних життєвих обставин, в яких суб'єкт набуває те, що здатне задовольнити представлену цим інтересом потребу [9, с. 13]. До властивостей інтересу відносять усвідомлення необхідності реалізації потреб та можливостей для цього [10, с. 7].

На основі теоретичних підходів до проблем інтересу як правової категорії державні інтереси слід розглядати як інтереси, що усвідомлені, визнані державою як пріоритетні, необхідність реалізації яких існує в конкретних історичних умовах. Визнання інтересів з боку держави здійснюється шляхом їх закріплення, як правило, на рівні Конституції, деяких законів та міжнародних договорів і знаходить прояв у формулюванні (прямо або опосередковано) на рівні таких законодавчих актів цілей держави, яких вона повинна досягти. Державні інтереси мають в своїй основі загальносуспільні потреби і спрямовані на реалізацію цих потреб. Такі потреби мають загальну цінність. Вони $є$ потребами суспільства в цілому, але водночас пов'язані із задоволенням потреб громадян, колективів і держави. Державний інтерес також включає в себе правові засоби, які спрямовані на реалізацію цих загальносуспільних потреб і здатні ії забезпечити. Характер і коло таких засобів залежить від відповідної суспільної потреби конкретних обставин історичного, соціально-економічного, правового характеру, в яких існує необхідність реалізації даної потреби.

Прикладами державних інтересів сьогодні є інтереси захисту державного суверенітету, забезпечення територіальної цілісності держави, запобігання посяганням на засади національної безпеки та конституційного ладу, поглиблення участі держави в ряді міжнародних організацій з питань безпеки, забезпечення наближення національної правової системи до стандартів Європейського Союзу, удосконалення правових механізмів протидії правопорушенням, ефективність яких (ме- 
ханізмів) є недостатньою (таким як корупційні правопорушення, правопорушення проти законної господарської, інвестиційної діяльності) тощо.

Ознаки державних інтересів дозволяють виділити наступні аспекти співвідношення їх 3 правами людини.

Реалізація державних інтересів за своєю природою передбачає сприяння, створення умов для реалізації прав людини. Однією з ознак державних інтересів, що відмежовують їх від суміжних категорій (таких, як вузьковідомчі інтереси органів влади, посадових осіб, державних підприємств) $\epsilon$ те, що державні інтереси грунтуються на загальносуспільних потребах і спрямовані на їх задоволення. Характер таких загальносуспільних потреб передбачає, що їх реалізація сприяє, створює умови, нерідко є необхідною для реалізації або захисту прав людини. Реалізація цих прав може витікати із реалізації загальносуспільної потреби опосередковано, іноді через певний проміжок часу. Але задоволення такої загальносуспільної потреби необхідне для того, щоб права, законні інтереси осіб, колективів були в подальшому реалізовані. Тобто певне коло прав людини здатне отримати реалізацію за умови задоволення загальносуспільної потреби, покладеної в основу відповідного державного інтересу.

Це положення актуальне, незважаючи на те, що держава в процесі реалізації державних інтересів повинна втручатись в права людини, вдаватись до їх обмежень. Такі обмеження, якщо спрямовані на реалізацію дійсних державних інтересів, забезпечують реалізацію загальносуспільних потреб державно-правовими засобами. Реалізація даних потреб сприяє реалізації приватних прав особи, створює умови для цього. Це стосується прав широкого кола осіб, включаючи, принаймні опосередковано, осіб, права яких були спочатку піддані обмеженням в державних інтересах з боку держави.

Наприклад, у 2005 році було прийнято Закон України «Про заходи, спрямовані на забезпечення сталого функціонування підприємств паливно-енергетичного комплексу» [11]. Ним було запроваджено механізми обмеження приватних прав особи в державних інтересах, зокрема майнових прав кредиторів по певним видам договорів із підприємствами ПЕК. В основу державних інтересів, на реалізацію яких спрямовано закон 2005 року, були покладені загальносуспільні потреби. Як вказувалось у цьому законі, його метою було сприяння поліпшенню фінансового становища підприємств ПЕК та запобігання їх банкрутству. Реалізація даних потреб мала загальносуспільне значення. В разі відсутності реалізації такої потреби було б створено перешкоди для реалізації прав і законних інтересів широкого кола осіб, колективів, організацій, ускладнено, а іноді унеможливлено таку реалізацію. Це могло мати місце внаслідок руйнації сфери обігу енергетичних ресурсів, що ставило під загрозу забезпечення потреб населення, функціонування національної економіки в цілому. Така ситуація здатна була призвести до порушення прав громадян, їх законних інтересів, потреб в сфері споживання, ведення господарської діяльності, в фінансовій сфері тощо.

Таким чином, відсутність реалізації відповідної загальносуспільної потреби і державного інтересу, який на ній грунтується, призводить до становища, за якого створюються перешкоди у реалізації прав людини, умови для реалізації яких пов'язані із відповідною загальносуспільною потребою. Або такі права можуть бути безпосередньо порушеними. Дане положення, по суті, знайшло своє відображення в практиці Європейського суду 3 прав людини. В одному із рішень, в якому розглядалось питання про правомірність втручання держави в майнові права особи для задоволення загальних потреб, Суд вказав, що за певних обставин державна влада повинна втручатись у права людини, зокрема шляхом позбавлення особи певних майнових благ, соціальних пільг, виплат. В протилежному випадку буде знівельовано зміст цивільно-правового інституту безпідставного збагачення, порушено принцип справедливості щодо інших осіб-платників соціальних страхових внесків та засади розподілу фінансових ресурсів держави [12]. За таких наслідків, реалізація прав значного кола осіб, які (права) витікають, в даному випадку, із засад правового інституту безпідставного збагачення та принципу справедливості буде ускладнена або унеможливлена. Цитоване рішення Європейського суду ілюструє приклад того, як загальносуспільна потреба, покладена в основу державного інтересу, за своєю природою передбачає сприяння реалізації прав особи.

Висновки. Проблематика співвідношення державних інтересів є складною і багатоаспектною. 3 одного боку, держава в певних ситуаціях вимушена обмежувати приватні права в державному інтересі. Водночас за своєю природою реалізація державних інтересів при їх правильній ідентифікації забезпечує створення умов для реалізації, захисту прав людини. У цьому сенсі права людини виступають свого роду одним показником того, що юридичні механізми, які застосовують органи 
влади в державних інтересах, насправді спрямовані на реалізацію об'єктивно існуючих (аутентичних) державних інтересів. В основі таких інтересів завжди повинні знаходитись загальні потреби суспільного характеру, задоволення яких $€$ необхідним для забезпечення реалізації прав людини. Із цього положення витікає проблема реалізації державних інтересів із дотриманням рівноваги, балансу із правами людини, що є предметом подальших досліджень.

\section{Список використаних джерел}

1. Берестова I. Е. Публічні законні інтереси конституційного значення / I. Е. Берестова // Юридична Україна. № 7. $-2018 .-$ C. 4-10.

2. Пархоменко Н. М. Гарантії реалізації прав і свобод людини і громадянина: проблеми сутності та змісту / Н. М. Пархоменко // Правова держава. - Вип. 21. - 2010. - С.130-137.

3. Оніщенко H. М. Сучасне право: вимоги громадянського суспільства, виклики часу, потреби людини / Н. М. Оніщенко // Альманах права. - Вип.7. - 2016. - С. 25-29.

4. ПУблічне урядування, права людини і демократія: регіональний зріз євроінтеграції : моногр. / Кол. авторів; за заг. ред. М. В. Савчина. - Ужгород : вид-во УжНУ «Говерла», 2015.

5. Гріненко О. О. Конституційні гарантії права власності в Україні та практика Європейського суду з прав людини / О. О. Гріненко // Держава і право : зб. наукових праць. Юридичні науки. Вип. 72. - К. : Юридична думка, $2016-$ C.128-152.

6. Alain Pellet. Responsibility of States in Cases of Human-rights or Humanitarian-law Violations // The International Legal Order: Current Needs and Possible Responses - Leiden : Koninklijke Brill NV, 2017. - P. 231-251.

7. Ursula Kriebaum. Expropriation // International Investment Law: edited by M. Bungenberg, J. Griebel, S. Hobe, A. Reinisch. - Baden Baden: Nomos, 2015. - P. 959-1030.

8. Венедіктова I. Методологічні підходи до співвідношення понять «інтерес» і «потреба» при визначенні юридичної категорії «охоронюваний законом інтерес» / І. Венедіктова // Проблеми цивільного права: вісник. № 3 (66). - 2011. - C.129-137.

9. Заморська Л. І. Правовий інтерес у змісті норм права: інтегративний підхід / Л. І. Заморська // Вісник Південного регіонального центру НАПрН України. Теорія та історія держави і права; історія політичних і правових вчень, №5. - 2015. - С.8-13.

10. Сиренко В.Ф. Интересы - власть - управление / В. Ф. Сиренко. - К. : Наукова думка, 1991.

11. Про заходи, спрямовані на забезпечення сталого функціонування підприємств паливно-енергетичного комплексу : Закон України від 23 червня 2005 р. № 2711-IV [Електронний ресурс]. - Режим доступу : https://zakon. rada.gov.ua/laws/show/2711-15

12. Čakarević v. Croatia, no.48921/13, ECHR, Judgment, 26 April 2018, §79 [Електронний ресурс]. - Режим доступу : https://hudoc.echr.coe.int/eng\#\{«fulltext»:[«Čakarević\%20v.\%20Croatia»],»documentcollectionid2»:[«GRANDCH AMBER»,»CHAMBER»],»itemid»:[«001-182445»]\}

\section{References}

1. Berestova I. E. Publichni zakonni interesy konstytutsiinoho znachennia / I. E. Berestova // Yurydychna Ukraina, № 7. -2018 . - S. 6-7.

2. Parkhomenko N. M. Harantii realizatsii prav i svobod liudyny i hromadianyna: problemy sutnosti ta zmistu / N. M. Parkhomenko // Pravova derzhava, vyp. 21. - 2010. - S.130-137.

3. Onishchenko N. M. Suchasne pravo: vymohy hromadianskoho suspilstva, vyklyky chasu, potreby liudyny / N. M. Onishchenko // Almanakh prava, vyp. 7. - 2016. - S. 26.

4. Publichne uriaduvannia, prava liudyny i demokratiia: rehionalnyi zriz yevrointehratsii: monohrafiia / Kol. avtoriv; za zah. red. M.V. Savchyna. - Uzhhorod : vyd-vo UzhNU «Hoverla», 2015. - S.127-141.

5. Hrinenko $O$. $O$. Konstytutsiini harantii prava vlasnosti v Ukraini ta praktyka Yevropeiskoho sudu z prav liudyny / O. O. Hrinenko // Derzhava i pravo: Zb. naukovykh prats. Yurydychni nauky. Vypusk 72. - K.: «Iurydychna dumka», 2016 - S.128-152.

6. Alain Pellet. Responsibility of States in Cases of Human-rights or Humanitarian-law Violations // The International Legal Order: Current Needs and Possible Responses - Leiden : Koninklijke Brill NV, 2017. - P. 231-251.

7. Ursula Kriebaum. Expropriation // International Investment Law: edited by M. Bungenberg, J. Griebel, S. Hobe, A. Reinisch. - Baden Baden : Nomos, 2015. - P. 959-1030.

8. Venediktova I. Metodolohichni pidkhody do spivvidnoshennia poniat «interes» i «potreba» pry vyznachenni yurydychnoi katehorii «okhoroniuvanyi zakonom interes» / I.Venediktova // Problemy tsyvilnoho prava: Visnyk, № 3 (66). - 2011. - S.129-137.

9. Zamorska L. I. Pravovyi interes u zmisti norm prava: intehratyvnyi pidkhid / L.I. Zamorska //Visnyk Pivdennoho rehionalnoho tsentru NAPrN Ukrainy. Teoriia ta istoriia derzhavy i prava; istoriia politychnykh i pravovykh vchen, № 5. -2015 . - S. 8-13. 
10. Syrenko V. F. Ynteresu - vlast - upravlenye / V.F. Syrenko. - K. : Naukova dumka, 1991.

11. Pro zakhody, spriamovani na zabezpechennia staloho funktsionuvannia pidpryiemstv palyvno-enerhetychnoho kompleksu : Zakon Ukrainy vid 23 chervnia 2005 r. № 2711-IV [Elektronnyi resurs]. - Rezhym dostupu : https:// zakon.rada.gov.ua/laws/show/2711-15

12. Čakarević v. Croatia, no.48921/13, ECHR, Judgment, 26 April 2018, $§ 79$ [Elektronnyi resurs]. - Rezhym dostupu : https://hudoc.echr.coe.int/eng\#\{“fulltext”:[“Čakarević\%20v.\%20Croatia”],”documentcollectionid2”:[“GRANDCH AMBER","CHAMBER”],"itemid":[“001-182445”]\}

\section{Кубко А. Є. Державні інтереси і права людини: деякі питання співвідношення}

Стаття присвячена питанням державних інтересів у конктесті співвідношення державних інтересів із правами людини. У статті окреслюється правова природа державних інтересів з точки зору проблеми їх співвідношення із засадами прав людини, їх захистом і гарантіями. Державні інтереси розглядаються як визнані державою в актах вищої юридичної сили інтереси, які спрямовані на забезпечення загальних потреб суспільного характеру. Такі інтереси отримують реалізацію із використанням державно-правових засобів. Задоволення цих потреб забезпечує умови для реалізації прав особи. Тому здатність державних інтересів забезпечити реалізацію приватних прав широкого кола осіб виступає важливою ознакою дійсних державних інтересів, що відмежовує їх від суміжних понять, таких, як вузьковідомчі інтереси, інтереси посадових осіб, органів влади та ін.

Ключові слова: інтереси, державні інтереси, права людини, державна влада.

\section{Kubko A. The Interests of the State and the Human Rights: Some Issues of Interrelations}

The article is dedicated to the issues of the state interests in the context of their interrelation with the human rights. The modern trends giving rise to the topicality of the matter of the protection of the state interests are analyzed. In the current circumstances in which the state faces threat to the national sovereignty, territorial integrity and security the state interest protection is one of the priorities to be achieved in the law and the law-enforcement activities of the state. In the legislation the role of the state interests notion is increasing. To attain effective protection of the state interests the lawmaker and the governmental authorities have to apply the restrictions on as well as the interference with the human rights and freedoms. At the same time it is the human rights and their safeguards which constitute one of the basic legal values in the domestic legal order as well as from the perspective of the international community. The state's powers aimed at the state interests protection often come into a conflict of some kind with the human rights, with the safeguards of these and with the process of their enforcement. The balance between the protection of the state interests and the respect for the human rights is the core issue. The article addresses the nature of the state interests. The process of the state activities aimed as the state interests protection frequently faces the risk that these interests are not correctly identified and are substituted with the adjacent, quasi-state interests such as the interests of the separate governmental authorities, officials, state companies, etc. resulting in groundless restrictions of the human rights by the state and disregard, at the same time, of the genuine state interests. The state interests justifying the state's interference with the human rights are the interests based on the public needs, recognized by the state in its laws of the supreme legal force and capable of being attained through lawful mechanisms by the state. Such public needs which give rise to the state interests should be of the general importance that is capable of securing conditions for implementation of the human rights of the wide range of individuals. From this perspective the ability of the state interests to secure at least indirectly i.a. the realization of the human rights due to achievement of the public needs the respective state interests are based on serves as an indication of the genuine state interest which is of public importance and is to be implemented in the legal order.

Key words: interests, state interests, human rights, state power.

DOI: 10.33.66.3/2524-017X-2019-10-162-166 